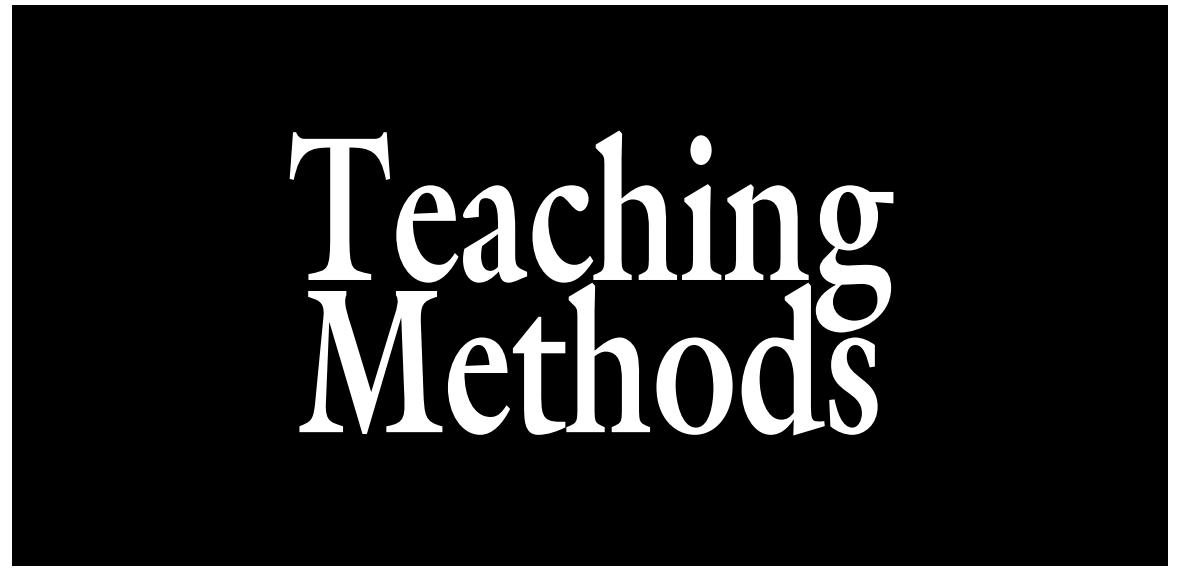

\section{A Horticulture Student Learning Outcome Assessment Plan for the University of Arkansas}

\author{
Garry V. McDonald ${ }^{1}$ and Wayne A. Mackay ${ }^{1}$
}

\begin{abstract}
ADDITIONAL INDEX WORDs. program assessment, student learning outcome, undergraduate education
\end{abstract}

\begin{abstract}
Summary. The University of Arkansas Horticulture Department was charged in 2016 by university administration to develop and implement a student learning outcome (SLO)-based assessment plan. The Horticulture Department curriculum committee was tasked to develop such a plan. Various models were considered, but ultimately a modified plan based on the work of M.P. Pritts and T. Park was adopted. Adjustments were based on student population size and particular requirements that had to be integrated with the university-mandated SLO goals and objectives. Two phases of a student's academic career were chosen to access: an incoming freshman or transfer phase and a late-term or degree completion phase. Specific learning outcomes and goals were identified as well as courses and activities that would reasonably be measured while meeting university requirements. Data collection on entering freshmen and transfer students started in Fall 2018. The full impact of the implemented plan will not be known until 2020, when the first full cohort of incoming freshmen reaches the terminal stage of the degree program.
\end{abstract}

I ncreasingly, SLOs are a part of the reaccreditation process for colleges and universities in the United States (Pritts and Park, 2013). Students are expected to master a minimum amount of learning based on instruction with measurable outcomes (Krathwohl, 2002). SLOs

$\overline{\text { Received for publication } 19 \text { Apr. 2019. Accepted for }}$ publication 10 July 2019.

Published online 27 August 2019.

${ }^{1}$ University of Arkansas, 316 Plant Science Building, Fayetteville, AR 7270

G.V.M. is a Clinical Assistant Professor.

W.A.M. is a Professor and Department Head.

G.V.M. is the corresponding author. E-mail: gmcdonal@ uark.edu.

This is an open access article distributed under the CC BY-NC-ND license (https://creativecommons.org/ licenses/by-nc-nd/4.0/).

https://doi.org/10.21273/HORTTECH04388-19 and restoration). Horticulture curricula, unless of a purely limited technical nature, include courses in basic science, aesthetics, humanities, public education, business, and social science (Pritts and Park, 2013). Combining science and art requires an educational model with the ability to synthesize and integrate knowledge from a wide spectrum of individual subjects (Dixon, 2005). Horticulture students must have a breadth and depth of understanding to amalgamate diverse knowledge into a unified whole (Dixon, 2005). The multidiscipline approach to horticulture curricula presents challenges when developing an assessment plan. The plan must assess a diverse range of student experiences and interests, as opposed to assessing majors with state/national certification licensing requirements and quantifiable benchmarks. The challenge for horticulture educators is to construct a curriculum that integrates many levels of knowledge and allows students to develop fully, being limited only by their ambition and achievement (Dixon, 2005).

Unlike many professional or accredited programs, horticulture as a discipline does not have national standards or accepted competencies content as part of a licensing or certification process. Although this does allow flexibility for each horticulture program to design a curriculum based on need, it may make the ability to compare student competency across horticulture programs in the country problematic; however, most horticulture educators/programs do follow a similar core content. During the 1980 s, an attempt was made by the American Society of Horticulture Science to establish a curriculum committee to review curricula content (Hegwood and Merritt, 1987). While providing guidelines for a Certified Professional Horticulturist certification, this committee failed to establish specific content and required skills. Other attempts have been made to recommend discipline-specific content that would facilitate a common approach to horticulture curricula. This would ensure potential employers that graduates have acquired, or at least have been exposed to, competencies needed to be a success in their chosen field (Basinger et al., 2009). Pritts and Park's (2013) work proposed a model of SLOs specific for horticulture 
programs in the United States. In 2016, the Department of Horticulture-Bumpers College of Agriculture and Life Sciences (Bumpers College AFLS) curriculum committee was charged to develop and implement an SLO assessment plan. The objective of this article is to report the results of that charge and plan implementation.

\section{Methods}

The initial approach was to evaluate assessment plans from other institutions with horticulture programs. Consultation with university administration provided guidelines on required assessment criteria based on a Higher Learning Commission (Chicago, IL) reaccreditation report for the University of Arkansas. The model system chosen was based on the 2013 work of Pritts and Park, with modifications, and is similar to the University of Florida Department of Environmental Horticulture. In addition, information on assessment methodology was gleaned from the Association of American Colleges and Universities (2016).

The committee defined two sets of direct assessment skills linked to SLOs. Set one is general educational outcomes consisting of written and oral communication, and critical thinking skills. Set two relates to horticulture core competency outcomes and includes 1) acquire, integrate, and apply knowledge of plant science to managed systems; 2) demonstrate interdisciplinary knowledge and competency in managing systems; 3) demonstrate knowledge synthesis and cognitive development to improve plant systems; 4 ) appreciate and communicate the diverse impacts of horticulture on people; and 5) demonstrate professionalism and proficiency in skills that relate to horticulture (Table 1 ).

A matrix of courses in the horticulture curriculum was constructed and each course was associated, if applicable, with one or more general or discipline-specific skills and SLOs (University of Arkansas Department of Horticulture, unpublished).

Assessment implementation. The course curriculum matrix was used to identify specific courses that would be part of the assessment implementation targeting specific

Table 1. Learning outcomes and goals for achieving core horticulture competency in discipline-specific skills as defined in the University of Arkansas Horticulture Department assessment plan.

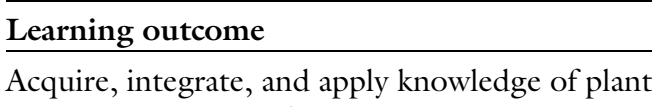

science to managed systems.

Demonstrate interdisciplinary knowledge and competency in managing a horticultural system.

Synthesize knowledge, and use insight and creativity to understand and improve plant systems more completely.

Appreciate and communicate the diverse impacts of horticulture on people.

Demonstrate professionalism and proficiency in skills that relate to horticulture.

\section{Goals}

Use multiple sources to find, evaluate, organize, and manage information. Demonstrate competency with laboratory and field-based technologies. Apply concepts of plant science to manage and improve plants. Apply scientific methods to test hypotheses.

Assess soils, soil health, plant fertility, water, and site limitations. Assess potential and evaluate realized interactions with the abiotic and biotic environment. Use appropriate application methods, materials, and diagnostic skills for addressing soil constraints and irrigation, nutrient, stress, and pest management issues. Apply principles of accounting, business law, labor, marketing, and personnel management to a horticultural business.

Anticipate and recognize problems, identify causes of those problems, quantify potential impacts, analyze options, and identify viable solutions. Develop, identify, and use best management practices that lead to sustainable outcomes. Understand how global issues affect the sustainability of horticultural systems.

Describe various ways plants affect human well-being. Describe and assess the influence of plants and their management on environmental sustainability, habitat restoration low-impact development. Quantify the economic importance of plants in managed ecosystems and their impact on food systems. Describe the social, spiritual, and cultural importance of plants to historical and contemporary communities of people. Communicate effectively with diverse audiences via multimedia.

Acquire knowledge of a range of cultures, values, and political perspectives relevant to living in a global community. Demonstrate a high level of personal and social responsibility. Demonstrate leadership and the ability to collaborate and work in teams. Plan, engage, and learn actions that demonstrate civic responsibility to community and society. Develop a plan for life-long learning as it relates to career choice and professionalism. 
SLOs as related to the overall horticulture program goals. It was recognized early on that a dual approach would be needed to track the two paths students use to enter the horticulture program. From 2013 to 2018, $25 \%$ of the horticulture majors at the University of Arkansas matriculated as true freshmen, 35\% transferred from other academic departments within the university, and $36 \%$ transferred from other academic institutions (Bumpers College AFLS, unpublished). Because of these various entryways, two models were implemented: an early assessment for both incoming freshmen and firstsemester transfer students, and a terminal or exit-level assessment.

EARLY-TRANSFER ASSESSMENT MODEL. The early-transfer assessment model (Table 2 ) is based partly on the requirement for all incoming freshmen to enroll in Univ 1001 University Perspectives. Incoming freshmen are grouped by Bumpers College as cohorts by major, so all horticulture students are captured during their first semester. The course allows for the direct assessment of oral and written communication skills and critical thinking at an entry point in the students' academic career. A second course incorporated into the early assessment model is Hort 2003 Principles of Horticulture. This course is normally taken either during the second semester of a student's freshmen year or as a sophomore. In addition, incoming transfer students take this course immediately after entering the program. Direct assessment for this class includes written and critical thinking skills in addition to basic core horticulture competencies. The third course comprising the early assessment model is Hort 2101 Career Development. This course is required before the end of a student's sophomore year or a transfer student's second semester. Direct learning assessed includes writing skills, oral communication, critical thinking, problem solving, knowledge integration, and professionalism. A main component of this course is the initial development and assessment of a student-centered eportfolio. The e-portfolio is a repository of a student's significant accomplishments demonstrating mastery of knowledge and skills over their academic tenure. The on-campus Career Development Center provides technical support and, upon their recommendation, LinkedIn (LinkedIn Corp., Sunnyvale, CA) was selected as the e-portfolio platform. All courses in this model are part of the core curriculum required for the Bachelor of Science degree in Horticulture Landscape and Turf Science.

LATE-TERMINAL ASSESSMENT. The late-terminal assessment model (Table 3) is directed at students approaching the end of their academic careers as seniors or within 1 year of graduation. Similar to the early-transfer model, all courses included in this assessment model are core classes required of all students. Hort 4403 Plant Propagation assesses written communication and critical thinking skills through an assigned research paper and advanced horticulture core competencies. A professional internship is required as part of the horticulture program and is a major component of the late-terminal model. Students normally complete their internship requirement between their junior and senior years, after they have acquired basic core competencies in disciplinerelated areas. The internship program was modified for use as part of the assessment process by creating two courses but still meeting the original 3-h core internship requirement. Apart from the assessment component, this course modification satisfied a number of newly mandated university policies concerning off-campus liability and continuous enrollment. Hort 462V Horticulture Internship Experience is the actual internship and has a writing component consisting of keeping a journal, or posting to a blog or other social media accessible to the student's advisor and the internship coordinator. The assessment component, Hort 472V Horticulture Internship Assessment, evaluates the internship and requires a seminar presentation and other requirements set by the student's advisor or the internship coordinator. Direct assessment includes oral, visual, and written communication skills in addition to critical thinking skills and horticulture core competency. During the individual student's final semester, the e-portfolio is assessed by faculty familiar with the student's academic program using a rubric based on progression and final development from the initial e-portfolio.

A S SESSMENT DATA AN D REPORTING. For each of the horticulture courses and components used as part of the assessment models, a scoring rubric is used to evaluate each student. The evaluation score ranges from levels 1 to 4 and was modified from the Association of American Colleges and Universities rubric for written communication (Association of American Colleges and Universities, 2016). A score of zero may be assigned if a student fails to achieve the minimal level 1 competency benchmark for that learning outcome. A score at level 4 indicates a student has mastered competency or has reached a capstone level for the learning outcome. Because each course has a set of rubrics for each SLO, for brevity and to illustrate, the rubric for written communication is shown (Table 4) in addition to the rubric used for learning outcome 1 for horticulture core competency goals (Table 5). Data collected for each student are compiled and used to generate a yearly assessment report as mandated by the university and Bumpers College. In addition to direct evaluations derived from course data, information on student success and an exit interview and survey conducted by

Table 2. Early and transfer model used in the University of Arkansas Department of Horticulture student learning outcome plan to assess incoming freshmen and first- or second-semester transfer students.

\begin{tabular}{lcc}
\hline Course $^{\mathrm{z}}$ & Learning outcome assessed & Assessment instrument \\
\hline Univ 1001 University Perspectives & Communication and critical thinking skills & $\begin{array}{c}\text { Reflective writing and problem-solving } \\
\text { exercises }\end{array}$ \\
$\begin{array}{ll}\text { Hort 2003 Principles of } \\
\text { Horticulture }\end{array}$ & $\begin{array}{c}\text { Critical thinking and basic horticulture core } \\
\text { competency }\end{array}$ & $\begin{array}{c}\text { Classroom modules and problem-solving } \\
\text { exercises }\end{array}$ \\
Hort 2101 Career Development & Written and visual communication skills & E-portfolio development \\
\hline
\end{tabular}

${ }^{\mathrm{z}}$ Courses listed are part of the horticulture core curriculum for a Bachelor of Science degree in Horticulture Landscape and Turf Sciences. 
Table 3. Late and terminal model for the University of Arkansas Department of Horticulture student learning outcome plan.

\begin{tabular}{lcc}
\hline Course $^{\mathrm{z}}$ & \multicolumn{1}{c}{ Learning outcome assessed } & Assessment instrument \\
\hline Hort 4403 Plant Propagation & $\begin{array}{c}\text { Writing and critical thinking skills, advanced } \\
\text { horticulture core competency }\end{array}$ & Term research paper \\
Hort 462V Internship Experience & $\begin{array}{c}\text { Writing and critical thinking skills, basic } \\
\text { horticulture core competency }\end{array}$ & $\begin{array}{c}\text { Journal or social media blog, midterm written or } \\
\text { oral evaluation }\end{array}$ \\
Hort 472V Horticulture & $\begin{array}{c}\text { Oral and visual communication skills, critical } \\
\text { thinking, and basic horticulture core }\end{array}$ & $\begin{array}{c}\text { Seminar presentation in the departmental } \\
\text { seminar series; final reports or projects as } \\
\text { Assessment }\end{array}$ \\
competency & assigned
\end{tabular}

${ }^{\mathrm{z}}$ Courses listed are part of the horticulture core curriculum for a Bachelor of Science degree in Horticulture Landscape and Turf Sciences.

Table 4. The University of Arkansas Department of Horticulture student learning outcome assessment implementation plan scoring rubric for written communication as modified from the Association of American Colleges and Universities (2016).

\begin{tabular}{|c|c|c|c|c|}
\hline Learning outcome & Capstone $4^{\mathrm{z}}$ & Milestone 3 & Milestone 2 & Benchmark 1 \\
\hline $\begin{array}{l}\text { Context and purpose } \\
\text { of writing }\end{array}$ & $\begin{array}{l}\text { Demonstrates a thorough } \\
\text { understanding of } \\
\text { context, audience, and } \\
\text { purpose; and focuses on } \\
\text { all elements of the work. }\end{array}$ & $\begin{array}{l}\text { Demonstrates adequate } \\
\text { consideration of } \\
\text { context, audience, and } \\
\text { purpose with a clear } \\
\text { focus on audience, } \\
\text { purpose, and content. }\end{array}$ & $\begin{array}{l}\text { Demonstrates awareness } \\
\text { of context, audience, } \\
\text { purpose to audience, } \\
\text { and content. }\end{array}$ & $\begin{array}{l}\text { Demonstrates minimal } \\
\text { attention to context, } \\
\text { audience, purpose, and } \\
\text { content. }\end{array}$ \\
\hline $\begin{array}{l}\text { Genre and discipline- } \\
\text { specific } \\
\text { conventions }\end{array}$ & $\begin{array}{l}\text { Demonstrates detailed } \\
\text { attention to and } \\
\text { successful execution of } \\
\text { a wide range of } \\
\text { conventions particular to } \\
\text { a specific discipline, } \\
\text { including organization, } \\
\text { content, presentation, } \\
\text { formatting, and stylistic } \\
\text { choices. }\end{array}$ & $\begin{array}{l}\text { Demonstrates consistent } \\
\text { use of important } \\
\text { conventions particular } \\
\text { to a specific discipline, } \\
\text { including organization, } \\
\text { content, presentation, } \\
\text { and stylistic choices. }\end{array}$ & $\begin{array}{l}\text { Follows expectations } \\
\text { appropriate to a specific } \\
\text { discipline for basic } \\
\text { organization, content, } \\
\text { and presentation. }\end{array}$ & $\begin{array}{l}\text { Attempts to use } \\
\text { a consistent system for } \\
\text { basic organization and } \\
\text { presentation. }\end{array}$ \\
\hline Sources and evidence & $\begin{array}{l}\text { Uses skillful, high-quality, } \\
\text { credible, and relevant } \\
\text { sources. }\end{array}$ & $\begin{array}{l}\text { Demonstrates a consistent } \\
\text { use of credible, relevant } \\
\text { sources to support ideas. }\end{array}$ & $\begin{array}{l}\text { Attempts to use credible } \\
\text { and relevant sources to } \\
\text { support ideas. }\end{array}$ & $\begin{array}{l}\text { Demonstrates an attempt } \\
\text { to use sources to } \\
\text { support ideas. }\end{array}$ \\
\hline Syntax and mechanics & $\begin{array}{l}\text { Communicates meaning } \\
\text { skillfully to readers with } \\
\text { clarity and fluency, and is } \\
\text { virtually error free. }\end{array}$ & $\begin{array}{l}\text { Uses straightforward } \\
\text { language that generally } \\
\text { conveys meaning to } \\
\text { readers, with few errors. }\end{array}$ & $\begin{array}{l}\text { Uses language that } \\
\text { generally conveys } \\
\text { meaning to readers, } \\
\text { although may include } \\
\text { errors. }\end{array}$ & $\begin{array}{l}\text { Uses language that } \\
\text { sometimes impedes } \\
\text { meaning because of } \\
\text { errors in use. }\end{array}$ \\
\hline
\end{tabular}

${ }^{\mathrm{z}} \mathrm{A}$ score of zero may be assigned to any writing sample that does not meet the level 1 benchmark.

the department head for each exiting student are used in the assessment report. During the exit interview, the department head questions students on the perceived quality of their horticultural education, and solicits feedback on strengths and weaknesses of course content and instructors.

\section{Results and discussion}

To implement the SLO assessment plan, during the Fall 2018 semester, initial data were collected in Univ 1001 University Perspectives on incoming freshmen. Writing samples were scored in addition to course modules that assessed critical thinking skills. Hort 2101 Career Development was restructured during the Spring 2018 semester to include modules using LinkedIn to build a base eportfolio. Students were required to connect with the department's assessment coordinator and the course instructor. Individual student e-portfolios are assessed for content improvement during that student's exiting semester. Data were collected from Hort 4403
Plant Propagation students on their writing skills and critical thinking skills by scoring the required research paper. The new internship program requirements and data collection were initiated at the beginning of the Summer 2018 internship period. Exit interviews were conducted in May 2018 for spring and summer graduating seniors. Assessment instruments and grading rubrics for Hort 2103 are still currently under development, but will be initiated at the beginning of Fall 2019. 
Table 5. The University of Arkansas Department of Horticulture student learning outcome discipline-specific rubric for learning outcome 1: acquire, integrate, and apply knowledge of plant science to managed horticultural systems.

\begin{tabular}{|c|c|c|c|c|}
\hline Goals & Capstone $4^{\mathrm{z}}$ & Milestone 3 & Milestone 2 & Benchmark 1 \\
\hline $\begin{array}{l}\text { Use multiple sources, } \\
\text { including current and } \\
\text { older literature, to } \\
\text { find, evaluate, } \\
\text { organize, and manage } \\
\text { information related to } \\
\text { horticultural systems. }\end{array}$ & $\begin{array}{l}\text { Publishes an article on } \\
\text { a plant-based system } \\
\text { with a thorough } \\
\text { literature review. }\end{array}$ & $\begin{array}{l}\text { Writes a thorough } \\
\text { literature review about } \\
\text { a specific topic for } \\
\text { classroom credit. }\end{array}$ & $\begin{array}{l}\text { Writes a term paper using } \\
\text { primary resources } \\
\text { related to a horticultural } \\
\text { topic. }\end{array}$ & $\begin{array}{l}\text { Is able to identify primary } \\
\text { and secondary } \\
\text { information sources } \\
\text { and differentiate } \\
\text { between referred and } \\
\text { nonreferred sources. }\end{array}$ \\
\hline $\begin{array}{l}\text { Apply concepts of plant } \\
\text { biology, systematics, } \\
\text { ecology, and genetics } \\
\text { to manage and } \\
\text { improve plants and } \\
\text { their products. }\end{array}$ & $\begin{array}{l}\text { Conducts capstone } \\
\text { research project related } \\
\text { to genetics, plant } \\
\text { physiology, plant } \\
\text { identification, or other } \\
\text { areas. }\end{array}$ & $\begin{array}{l}\text { Develops a plant } \\
\text { selection guide for use } \\
\text { in a specific } \\
\text { horticultural system as } \\
\text { part of a class } \\
\text { assignment. }\end{array}$ & $\begin{array}{l}\text { Completes courses in } \\
\text { fruit/vegetable/ } \\
\text { landscape/turf } \\
\text { management, and } \\
\text { understands the } \\
\text { selection and appropriate } \\
\text { use of plants unique to } \\
\text { those courses. }\end{array}$ & $\begin{array}{l}\text { Completes at least one } \\
\text { course in plant } \\
\text { identification, } \\
\text { taxonomy/systematics, } \\
\text { or genetics. }\end{array}$ \\
\hline $\begin{array}{l}\text { Apply scientific methods } \\
\text { to test hypothesis. }\end{array}$ & $\begin{array}{l}\text { Writes, submits to peer or } \\
\text { instructor evaluation, } \\
\text { defends a capstone } \\
\text { research thesis. Gives } \\
\text { a public presentation of } \\
\text { the work. }\end{array}$ & $\begin{array}{l}\text { Writes a research } \\
\text { proposal and conducts } \\
\text { a research project } \\
\text { leading to a published } \\
\text { or presented paper. }\end{array}$ & $\begin{array}{l}\text { Writes a research proposal } \\
\text { and conducts a research } \\
\text { project leading to } \\
\text { a summary paper as } \\
\text { a special topic. }\end{array}$ & $\begin{array}{l}\text { Conducts classroom } \\
\text { laboratory experiments } \\
\text { with hypothesis testing, } \\
\text { data collection, and } \\
\text { analysis, and } \\
\text { conclusions. }\end{array}$ \\
\hline
\end{tabular}

${ }^{\mathrm{z}}$ A score of zero may be assigned to any goal does not meet the level 1 benchmark.

Modified from Pritts and Park (2013).

In addition to the previous criteria, which are based on scoring rubrics of direct SLO, another metric included in the assessment report is student success. Student success is defined as a capstone (level 4) achievement of student involvement among the following: special problem courses, research paper presentations or professional organization meetings attended, honors program completion, student leadership, community involvement, awards and recognitions, sustainability minors, or other accomplishments showing superior discipline competencies. The exit interview, although subjective, is useful to gauge student attitudes and perceptions on the quality of the overall learning experience.

Data collection on incoming freshmen began in Fall 2018. It will be 3 years before a complete cycle of 120 credit hours required for the bachelor's degree will be available for a full evaluation of SLO. Data collected for the late-terminal assessment will be used to generate the annual report until full data are available.
The described implementation plan is tailored for University of Arkansas' horticulture program, which traditionally has a small number of incoming freshmen each fall and manageable numbers of transfers each year. This enrollment pattern each year makes tracking student progress less onerous. Even so, systematic recording and tracking of SLO requires a commitment to provide resources and personnel to manage the assessment plan. Although the SLO is currently approved by the college and university, the SLO is expected to be a living, changing document. Therefore, moving forward, it is anticipated that change, improvements, and modifications to the assessment plan will be implemented.

\section{Literature cited}

Association of American Colleges and Universities. 2010. Rising to the challenge: Meaningful assessment of student learning. 2 Feb. 2019. <http:// www.eric.ed.gov/PDFS?ED519804. $\mathrm{pdf}>$.
Association of American Colleges and Universities. 2016. VALUE rubric. 15 Oct. 2018. <http://Value@aacu.org>.

Basinger, A.R., C.B. McKenney, and D. Auld. 2009. Competencies for a United States horticulture undergraduate major: A national Delphi study. HortTechnology 19:452-458.

Dixon, G.R. 2005. A review of horticulture as an evolving scholarship and the implications for educational provision. Acta Hort. 672:25-34.

Hegwood, D.R. and R.H. Merritt. 1987. Horticulture curricula can benefit from national initiatives. HortScience 22:351352.

Krathwohl, D.R. 2002. A revision of Bloom's taxonomy: An overview. Theory Pract. 41:212-218.

Pritts, M.P. and T. Park. 2013. Proposed learning outcomes for four-year horticultural programs in the United States. HortTechnology 23:237-240. 